\title{
Pengaruh Lama Penyimpanan Telur Tetas Ayam Kedu Jengger Merah terhadap Kualitas Interior Telur
}

\section{Effect of Storage Time of Hatching Eggs of Red Comb Kedu Chicken on the Interior Quality}

\author{
U. Latifah, S. Kismiati dan Sutopo \\ Fakultas Peternakan dan Pertanian Universitas Diponegoro, \\ Jl. Prof. H. Soedarto, S.H - Tembalang, Semarang 50275 - Indonesia \\ Corresponding email: umilatifah583@gmail.com
}

\begin{abstract}
The study aimed to evaluate the effect of storage time on the interior quality. The material used is 113 eggs of Red Comb Kedu Chicken. The design used was a Complete Random Design (CRD) with 5 treatments and 5 replications. The treatments used were egg storage 1 day (T0), egg storage 3 days (T1), egg storage 5 days (T2), egg storage 7 days (T3) and egg storage 9 days (T4). Parameters observed included albumen weight, yolk weight and haugh unit. The results showed that storage time had a significant effect $(\mathrm{P}<0.05)$ on albumen weight and haugh unit, but did not significantly influence yolk weight. Albumen weight began to decline in treatment T3, while in haugh unit decreased in treatment T1. It was concluded that the longer of hatching eggs stored, would reduce the interior quality.
\end{abstract}

Key words: Kedu chicken; quality; interior, haugh units.

\begin{abstract}
ABSTRAK
Penelitian bertujuan untuk mengevaluasi pengaruh lama penyimpanan terhadap kualitas interior telur ayam Kedu jengger merah. Materi yang digunakan adalah 113 butir telur ayam kedu jengger merah. Rancangan yang digunakan adalah Rancangan Acak Lengkap (RAL) dengan 5 perlakuan dan 5 ulangan. Perlakuan yang digunakan yaitu penyimpanan telur 1 hari (T0), penyimpanan telur 3 hari (T1), penyimpanan telur 5 hari (T2), penyimpanan telur 7 hari (T3) dan penyimpanan telur 9 hari (T4). Parameter yang diamati meliputi bobot putih telur, bobot kuning telur dan haugh unit. Hasil penelitian menunjukkan bahwa lama penyimpanan berpengaruh nyata $(\mathrm{P}<0,05)$ terhadap bobot putih telur dan haugh unit, tetapi tidak berpengaruh nyata terhadap bobot kuning telur. Bobot putih telur mulai menurun pada perlakuan T3, sedangkan pada haugh unit menurun pada perlakuan T1. Disimpulkan bahwa semakin lama telur tetas disimpan akan menurunkan kualitas interior.
\end{abstract}

Kata kunci: ayam Kedu; kualitas; interior, haugh unit.

\section{PENDAHULUAN}

Ayam Kedu merupakan salah satu plasma nutfah ayam lokal Indonesia yang mempunyai karakteristik khas dan berbeda dari ayam lokal lainnya sehingga perlu adanya pelestarian ayam Kedu. Menurut Dinas Peternakan dan Perikanan Pemerintah Kabupaten Temanggung (2011) populasi ayam Kedu pada tahun 2011 di Kabupaten Temanggung sebesar 22.637 ekor. Ayam Kedu adalah salah satu varietas ayam lokal Indonesia.

Ayam Kedu dibedakan menjadi 4 jenis berdasarkan warna bulu yaitu ayam Kedu cemani, ayam Kedu putih, ayam Kedu hitam dan ayam Kedu merah (Rukmana, 2003). Berdasarkan data yang ada di Satker Maron, Temanggung, Jawa Tengah Ayam Kedu dibedakan menjadi ayam Kedu hitam, ayam
Kedu putih dan ayam Kedu lurik. Namun berdasarkan warna jenggernya maka ayam Kedu dibedakan menjadi 2 jenis yaitu ayam Kedu hitam jengger hitam dan ayam Kedu hitam jengger merah. Ayam Kedu jengger merah memiliki ciri-ciri yang khas yaitu bulu berwarna hitam mengkilap, jengger, pial serta cuping berwarna merah, kaki berwarna putih kehitaman.

Ayam Kedu berasal dari Desa Kedu yang berada di Kabupaten Temanggung. Perkembangbiakan dan populasi ayam Kedu di Indonesia masih relatif rendah oleh sebab itu perlu adanya upaya agar populasi ayam Kedu semakin meningkat. Salah satu diantaranya yaitu dengan melakukan manajemen telur tetas ayam Kedu dengan baik terutama yaitu lama penyimpanan telur dengan tujuan untuk 
menemukan lama penyimpanan terbaik yang diharapkan dapat memaksimalkan hasil dari penetasan telur. Produktivitas yang dimiliki ayam Kedu relatif rendah dan sangat lambat meskipun mempunyai keunggulan komparatif secara genetis (Suthama, 2006).

Penelitian ini bertujuan untuk mengetahui pengaruh lama penyimpanan terhadap kualitas interior telur ayam Kedu jengger merah di Satker Maron, Temanggung, Jawa Tengah. Manfaat dari penelitian yaitu dapat mengetahui maksimal lama penyimpanan telur tetas ayam Kedu jengger merah yang dapat dijadikan sebagai salah satu faktor keberhasilan pada penetasan.

\section{MATERI DAN METODE}

Penelitian ini dilaksanakan pada bulan Mei - September 2018. Materi yang digunakan yaitu telur tetas sebanyak 113 dengan rata-rata bobot telur 42,187 \pm 8,562 g dari ayam Kedu jengger merah generasi ke 3 dengan umur \pm 68 minggu. Ayam Kedu jengger merah yang digunakan sebanyak 30 ekor yang dibagi menjadi 5 pen dengan perbandingan 1:5. Alat yang digunakan meliputi, egg tray sebagai tempat telur, depth micrometer untuk mengukur tinggi putih telur, kaca untuk alas tempat memecah telur, timbangan untuk menimbang telur, putih telur dan kuning telur, sendok untuk memisahkan putih dan kuning telur, plastik untuk tempat kuning telur, alat tulis untuk mencatat data hasil penelitian. Metode penelitian dilaksanakan dengan tiga tahap yaitu tahap persiapan, tahap pelaksanaan dan analisis data.

\section{Tahap Persiapan}

Tahap persiapan penelitian dimulai dengan sanitasi kandang yang akan digunakan untuk kandang induk ayam Kedu. Kemudian dilakukan pemilihan induk dan penimbangan induk ayam Kedu jengger merah. Induk yang sudah ditimbang dipelihara dikandang litter dengan ukuran setiap pen $100 \times 234 \mathrm{~cm}$ yang sudah dipersiapkan dan dikelompokkan berdasarkan bobot badan yang tidak berbeda jauh dalam satu pen. Kandungan nutrien pakan yang diberikan yaitu kadar air 9,78\%, abu 10,62\%, lemak kasar 2,60\%, serat kasar $11,27 \%$ dan protein kasar $12,15 \%$ dalam $100 \%$ bahan kering. Pemberian pakan diberikan sebanyak 2 kali sehari yaitu pada pagi dan sore hari, air minum diberikan secara adlibitum serta penambahan vitamin 2 hari sekali. Telur yang dihasilkan selama 3 minggu pertama tidak digunakan pada data penelitian agar sisa semen dari jantan sebelumya sudah tidak mempengaruhi telur yang akan diambil sebagai data penelitian.

\section{Tahap Pelaksanaan}

Tahap pelaksanaan yaitu telur dikumpulkan setiap hari selama 10 hari dan disimpan di tempat penyimpanan pada suhu ruang dengan rata-rata suhu pagi $21,22^{\circ} \mathrm{C}$, siang $23,47{ }^{\circ} \mathrm{C}$, sore $23,94^{\circ} \mathrm{C}$ dengan kelembapan pagi $65,55 \%$, siang $60,45 \%$ dan sore $58,33 \%$, serta dilakukan pemberian kode identitas pada setiap telur diantaranya generai telur, asal pen, periode telur, nomor telur dan hari penyimpanan telur. Telur yang telah di disimpan sesuai perlakuan dilakukan pengukuran parameter yang meliputi bobot putih telur, bobot kuning telur dan haugh unit.

Data yang diperoleh dihitung nilai haugh unit, menurut Buckle et al., (1986):

$$
\begin{aligned}
& \mathrm{HU}=100 \mathrm{Log}\left(\mathrm{H}+7,57-1,7 \mathrm{~W}^{0,37}\right) \\
& \mathrm{H}=\text { tinggi putih telur }(\mathrm{mm}) \\
& \mathrm{W}=\text { bobot telur }(\mathrm{g})
\end{aligned}
$$

\section{Tahap Analisis Data}

Rancangan yang digunakan adalah Rancangan Acak Lengkap (RAL) dengan 5 perlakuan dan 5 ulangan. Perlakuan yang diberikan yaitu sebagai berikut:

T0: lama penyimpanan 1 hari

T1: lama penyimpanan 3 hari

T2: lama penyimpanan 5 hari

T3: lama penyimpanan 7 hari

T4: lama penyimpanan 9 hari

Data yang diperoleh dianalisis menggunakan uji ANOVA, apabila hasil analisis menunjukkan pengaruh yang nyata maka dilanjutkan dengan analisis Duncan's New Multiple Range Test (MRT). Pengolahan data menggunakan program Statistycal Analisis System (SAS) versi 9.1.

\section{HASIL DAN PEMBAHASAN}

Hasil penelitian menunjukkan bahwa lama penyimpanan berpengaruh nyata $(\mathrm{P}<0,05)$ terhadap bobot putih telur dan haugh unit, tetapi tidak berpengaruh nyata terhadap bobot kuning telur. Rataan bobot putih telur, bobot kuning telur dan haugh unit. 
Tabel 1. Rataan bobot putih telur ayam Kedu Jengger Merah

\begin{tabular}{|c|c|c|c|c|c|}
\hline \multirow{2}{*}{ Ulangan } & \multicolumn{5}{|c|}{ Perlakuan } \\
\hline & T0 & T1 & $\mathrm{T} 2$ & T3 & T4 \\
\hline & \multicolumn{5}{|c|}{ 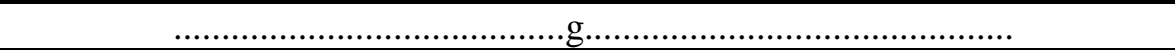 } \\
\hline 1 & 26,24 & 25,73 & 23,14 & 23,19 & 27,60 \\
\hline 2 & 29,93 & 27,84 & 28,15 & 24,85 & 26,37 \\
\hline 3 & 25,67 & 26,55 & 24,14 & 22,57 & 25,71 \\
\hline 4 & 24,91 & 25,24 & 23,01 & 23,40 & 22,26 \\
\hline 5 & 23,19 & 25,12 & 23,92 & 21,82 & 24,34 \\
\hline Rata-rata & $25,988^{\mathrm{a}}$ & $26,096^{\mathrm{a}}$ & $24,472^{\text {ba }}$ & $23,165^{b}$ & $25,256^{\mathrm{ba}}$ \\
\hline
\end{tabular}

Keterangan: superskrip pada baris yang berbeda menunjukkan perbedaan nyata $(\mathrm{p}<0,05)$

Tabel 1 dijelaskan bahwa semakin lama penyimpanan semakin menurunkan bobot putih telur, bobot putih telur paling rendah pada penyimpanan 7 hari (T3). Penurunan bobot putih telur disebabkan oleh proses penguapan air pada telur sehingga menyebabkan bobot putih telur semakin lama disimpan semakin berkurang. Hasil penelitian yang dilakukan oleh Scot dan Silversides (2000) bahwa telur yang dismipan selama $1 ; 3 ; 5$; dan 10 hari dengan suhu $20,2^{\circ} \mathrm{C}$ menunjukkan semakin lama telur disimpan maka bobot putih telur semakin menurun secara nyata, sedangkan hasil penelitian Silverdes dan Budgell (2004) telur yang disimpan selama $1 ; 3 ; 5$ dan 10 hari menunjukkan penurunan bobot putih terjadi setelah penyimpanan selama 5 hari. Menurut Dudusola (2009), telur yang disimpan selama 0; 4; 7 dan 21 hari kadar air telur menunjukkan terjadi penurunan secara nyata.

Tabel 2 ditunjukkan bahwa lama penyimpanan, tidak berpengaruh nyata terhadap bobot kuning telur. Hasil penelitian Akyurek dan Okur (2009) bahwa bobot kuning telur pada penyimpanan 3; 7; 10 dan 14 hari tidak berbeda nyata. Meskipun lama penyimpanan terhadap bobot kuning telur pada superskrip menunjukkan tidak adanya perbedaan yang nyata tetapi secara angka bobot kuning telur cenderung naik. Penelitian Scot dan Silverdes (2000) juga menyatakan bahwa lama penyimpanan telur $1 ; 3$; 5 dan 10 hari bobot kuning telur mengalami kenaikan yang dimulai pada penyimpanan 3 hari. Bobot kuning telur yang tidak berbeda nyata dikarenakan pada lama penyimpanan $1 ; 3 ; 5 ; 7$ maupun 9 hari penambahan air dari putih telur ke kuning telur tidak terlalu banyak sehingga bobot kuning telur tidak menunjukkan adanya perbedaan yang nyata. Sesuai dengan penelitian Anggraini (2011) bahwa lama penyimpanan telur ayam pada $2 ; 5$ dan 8 hari tidak berpengaruh terhadap kadar air yang terkandung pada kuning telur. Faktor lain yang mempengaruhi bobot kuning telur adalah kadar lemak pada kuning telur, lemak pada kuning telur merupakan bagian terbesar pada kuning telur. Menurut Yuwanta (2010) kuning telur memiliki kandungan lemak $32-36 \%$, protein $16 \%$ dan air $50 \%$, sedangkan berat kering kuning telur yang menempati $2 / 3$ bagian yaitu lipovitelin yang mengandung lemak sebanyak90\%. Sesuai dengan pendapat Agro et al. (2013) bahwa penyimpanan lemak paling banyak pada telur berada pada kuning telur, sehingga lemak pada kuning telur mempengaruhi berat kuning telur.

Tabel 2. Rataan bobot kuning telur ayam Kedu Jengger Merah

\begin{tabular}{|c|c|c|c|c|c|}
\hline \multirow{2}{*}{ Ulangan } & \multicolumn{5}{|c|}{ Perlakuan } \\
\hline & T0 & $\mathrm{T} 1$ & $\mathrm{~T} 2$ & T3 & $\mathrm{T} 4$ \\
\hline & & & .......g...... & …...... & \\
\hline 1 & 16,20 & 15,77 & 15,89 & 18,93 & 17,89 \\
\hline 2 & 16,37 & 16,35 & 16,66 & 17,03 & 15,97 \\
\hline 3 & 16,48 & 17,58 & 17,39 & 15,61 & 16,68 \\
\hline 4 & 15,69 & 15,65 & 15,74 & 17,16 & 17,57 \\
\hline 5 & 15,29 & 16,65 & 15,32 & 15,55 & 16,14 \\
\hline Rata-rata & 16,004 & 16,399 & 16,199 & 16,856 & 16,849 \\
\hline
\end{tabular}

Keterangan: superskrip pada baris yang berbeda menunjukkan perbedaan tidak nyata $(\mathrm{p}>0,05)$ 
Tabel 3. Rataan haugh unit ayam Kedu Jengger Merah

\begin{tabular}{crrrrr}
\hline \multirow{2}{*}{ Ulangan } & \multicolumn{5}{c}{ Perlakuan } \\
\cline { 2 - 6 } & T0 & T1 & T2 & T3 & T4 \\
\hline & & $\ldots \ldots \ldots \ldots \ldots \ldots \ldots \ldots \ldots \ldots \ldots \ldots \ldots \ldots \ldots \ldots \ldots \ldots \ldots \ldots \ldots \ldots \ldots \ldots \ldots \ldots \ldots \ldots \ldots \ldots \ldots \ldots \ldots \ldots$ & \\
2 & 49,56 & 49,54 & 43,42 & 38,91 & 26,88 \\
3 & 58,70 & 48,16 & 41,28 & 27,88 & 25,49 \\
4 & 59,27 & 40,98 & 46,60 & 39,99 & 41,31 \\
5 & 58,26 & 40,88 & 46,49 & 30,64 & 38,51 \\
Rata-rata & 51,67 & 34,02 & 40,17 & 40,93 & 35,52 \\
\hline
\end{tabular}

Keterangan: superskrip pada baris yang berbeda menunjukkan perbedaan nyata $(p<0,05)$

Telur semakin lama disimpan berpengaruh nyata terhadap haugh unit (Table 3 ). Penurunan nilai haugh unit dimulai pada penyimpanan T1 (3 hari), sedangkan haugh unit paling rendah yaitu pada penyimpanan T4. Scot dan Silversides (2000) menyatakan bahwa penyimpanan $1 ; 3 ; 5 ; 7$ dan 10 hari pada telur menyebabkan tinggi putih telur semakin menurun secara signifikan. Penelitian yang dilakukan Tabidi (2011) juga memperoleh hasil bahwa perlakuan penyimpanan telur secara signifikan menurunkan tinggi putih telur dan haugh unit. Hasil penelitian Oleforuh et al. (2016) juga menunjukkan bahwa semakin lama penyimpanan telur semakin menurunkan haugh unit. Penurunan haugh unit dipengaruhi oleh berat telur dan tinggi putih telur selama penyimpanan, semakin lama disimpan berat telur dan tinggi putih telur semakin menurun. Silverder dan Budgell (2004) bahwa berat telur dan tinggi albumen semakin menurun seiring dengan waktu lama penyimpanan telur.

\section{KESIMPULAN}

Penyimpanan yang semakin lama pada telur tetas semakin menurunkan kualitas interior yang ditandai dengan menurunnya bobot putih telur dan haugh unit namun kualitas pada bobot kuning telur tidak menurun. Perlu adanya penelitian lebih lanjut terhadap kadar air, lemak dan protein di setiap bagian telur serta dilakukan penelitian menggunakan telur dari ayam lokal yang lain.

\section{DAFTAR PUSTAKA}

Akyurek, H dan A. A. Okur. 2009. Effect of storage time, temperature and hen age on egg quality in free-range layer hens. J. Animal and Veterinary Advances. 8 (10): 1953 - 1958.
Anggraini, S. M. 2011. Kajian sifat fisik, kimia dan mikrobiologi kuning telur yang ditambah madu dengan jenis dan umur telur yang berbeda. Fakultas Peternakan, Institut Pertanian Bogor, Bogor. (Skripsi).

Agro, L. B., Tristiarti dan I. Mangisah. 2013. Kualitas fisik telur ayam arab petelur fase i dengan berbagai level Azolla microphylla. J. Animal Agriculture. 2 (1): 445-447.

Buckle, K.A., R. Edward., G. H. Fleet and M. Wooton. 1986. I1mu Pangan. Diterjemahkan oleh H. Purnomo dan Adiono. U.L Press, Jakarta.

Dinas Peternakan dan Perikanan Kabupaten Tenmanggung. 2011. Statistik Peternakan Kabupaten Temanggung. Kabupaten Temanggung.

Dudusola, I. O. 2009. Effects of storage methods and length of storage on some quality parameters of Japanese quail eggs. J.Tropicultura. 27 (1): $45-48$.

Oleforuh, V. U., Okoleh dan J. Eze. 2016. Effect of storage period and method on internal egg quality traits of the Nigerian native chicken. J. Livestock Research for Rural Development. 28 (6). http://www.lrrd.org/lrrd28/6/olef28115.ht $\underline{\mathrm{ml}}$

Rukmana, H. R. 2003. Ayam Buras Identifikasi dan Kiat Pengembangan. Kanisius, Yogyakarta. 
Scot, T. A dan F. G. Silversides. 2000. The effect of storage and strain of hen on egg quality. J. Poultry Sciences. 79: $1725-1729$.

Silverdes, F. G dan K.Budgell. 2004. The relationships among measures of egg albumen height, $\mathrm{pH}$, and whipping volume. J. Poultry Science 83:1619- Yuwanta, T. 2010. Telur dan Kualitas Telur. 1623.

Suthama, N. 2006. Kajian aspek "protein turnover" tubuh pada ayam Kedu periode pertumbuhan. J. Media Peternakan. 29 (2): 47-53.

Tabidi, M. H. 2011. Impact of storage period and quality on composition of table egg. J. Advances in Environmental Biology. 5 (5): $856-861$.

Gajah Mada University Press, Yogyakarta. 